\title{
Microalgal taxonomic diversity from shallow acidophilus freshwater bodies from the south of Chile
}

\section{Diversidad taxonómica de microalgas en cuerpos dulceacuícolas someros y acidófilos del sur de Chile}

\author{
Mariela A. González ${ }^{1 *}$, Ingrid de L. Inostroza ${ }^{1}$, Visitación Conforti ${ }^{2}$ \& Enrique Ascencio ${ }^{1}$ \\ ${ }^{1}$ Laboratorio de Cultivo de Microalgas (FICOLAB), Departamento de Botánica, Facultad de Ciencias Naturales y Oceanográficas, Universidad de Concepción, Chile. \\ ${ }^{2}$ Departamento de Biodiversidad y Biología Experimental, Facultad de Ciencias Exactas y Naturales, Instituto de Biodiversidad y Biología Experimental y Aplicada, CONICET- \\ Universidad de Buenos Aires, Buenos Aires, Argentina. \\ *Email: mgonzale@udec.cl
}

\section{ABSTRACT}

This research is the first taxonomic approach about the microalgae inhabiting shallow acidophilus freshwater bodies (Chapito pool, "small dam" and Tepual stream) within the Katalapi Park, X Region, Chile. A total of 80 taxa were identified based on morphocytological attributes, being the Streptophyta-Zygnematophyceae the most abundant group with a dominance of Desmidiaceae ( 47 species), follow by Cyanobacteria (14), Euglenophyceae (12), Chlorophyta-Chlorophyceae (5), and Dinophyceae and Ochrophyta-Raphidophyceae with one taxon each group. The genera with the higher number of species were Cosmarium (12), Closterium (11) and Staurastrum (8). The $\mathrm{pH}$ ranged from 5.0 to 6.1 during the recollection period. Most of the desmids species identified $(70.2 \%)$ are from acidophilus environments, $48.6 \%$ are indicators of mesotrophy and $21.6 \%$ of meso-oligotrophic habitats. Twenty-four species are cited for the first time for Chile. Although the study was restricted to a relatively small area, the results suggest that a great diversity of microalgae might be also found in similar ecological areas within the country.

Keywords: blue-greens, desmids, morphology, photosynthetic euglenoids, taxonomy.

\section{RESUMEN}

Esta investigación es el primer aporte taxonómico sobre las microalgas que habitan en cuerpos de agua acidófilos, someros (Laguna Chapito, "pequeño tranque" y estero Tepual) al interior del Parque Katalapi, X Región, Chile. Se identificó un total de 80 taxa basado en atributos morfocitológicos, siendo el grupo Streptophyta-Zygnematophyceae el más abundante con dominancia de Desmidiaceae (47 especies), seguido por Cyanobacteria (14), Euglenophyceae (12), Chlorophyta-Chlorophyceae (5), y Dinophyceae y OchrophytaRaphidophyceae con un taxón cada grupo. Los géneros con el mayor número de especies fueron Cosmarium (12), Closterium (11) y Staurastrum (8). El rango de pH durante el periodo de recolección fluctuó entre 5,0 a 6,1. La mayoría de las especies de desmidiaceas identificadas (70,2\%) son de ambientes acidófilos, el 48,6 \% son indicadoras de mesotrofía y el $21,6 \%$ de hábitats meso-oligotróficos. Veinticuatro especies se citan por primera vez para Chile. Aunque el estudio estuvo restringido a un área relativamente pequeña, los resultados sugieren la potencialidad de encontrar una gran diversidad de microalgas en áreas ecológicas similares en el país.

Palabras clave: algas verde-azules, Desmidiaceas, euglenoides fotosintéticos, morfología, taxonomía. 


\section{INTRODUCTION}

The taxonomic knowledge about the microalgae inhabiting water bodies (pools, ponds, streams, rivers) within national parks in the last 50 years in Chile, is scarce. Several studies have been done in the National Park "Torres del Paine" (Soto et al. 1994, Campos et al. 1994a, b, Campos et al. 1996, De los Ríos \& Soto 2009) and in the northern Patagonian lakes Chapo (Villalobos et al. 2003) and Riñihue (Woelfl et al. 2003): however, most of them from a limnological point of view. So, only chlorophyll "a" or a list of the main phytoplankton species found in these water bodies were included. More recently, Palau \& Caputo (2013), characterized limnologically 15 pristine water bodies from the "Fundación San Ignacio de Huinay" area in the north Patagonia (X Region), where they identified 60 taxa of microalgae but mostly (70\%) at generic level. The only studies focused on the biodiversity of microalgae were those from Parra \& González (1977, 1978) on some lakes and other freshwater bodies (i.e. ponds, streams) from Chiloe Island, Theoduloz \& Parra (1984) on the Lake Systems of Cordillera del Paine, and Williamson (2004) from Laguna San Rafael National Park. The diatoms have been studied by Rose \& Cox (2002) from different benthic habitats within seven upland lakes in the Laguna San Rafael National Park and the presence of specific species by Rivera et al. (2002), in Lake Chungara (Stephanodiscus agassizensis Hakansson \& Kling), Rivera \& Cruces (2008) in Lauca River (both from Parque Nacional Lauca) (Fragilaria capucina var. mesogongyla Frenguelli) and by the same later authors (2015) in Salar Aguas Calientes and Salar de Huasco (Parque Nacional Salar del Huasco) (Frankophila sudamericana Rivera \& Cruces).

The present study was carried out in acidophilus freshwater bodies (a pond, a small reservoir and a stream) within the Katalapi Park, a protected area for more than two decades, with the aim to know the most common microalgae (excl. Diatoms) inhabiting those environments.

\section{MATERIAL AND METHODS}

The Katalapi Park $\left(41^{\circ} 31^{\prime} 12^{\prime \prime} \mathrm{S} ; 72^{\circ} 45^{\prime} 42^{\prime \prime} \mathrm{W}\right)$ is located within the Ecoregion of the Valdivian Temperate Rain Forest, which has a high degree of endemism. It is a private protected area since 1994, created to support scientific research linked to the native forest. The park has 28 ha (about 56 acres) of native forest and open fields. Water bodies are abundant in the park (streams, a pool and ponds).
The water bodies under study were: the Chapito pool, a very shallow pool of approximately 20 to $80 \mathrm{~cm}$ depth and 30 m length $\times 10$ m wide (Fig. 1a); a "small dam"of 10 m length $x 5 \mathrm{~m}$ wide with a depth fluctuating between $30 \mathrm{~cm}$ to $2 \mathrm{~m}$ (Fig. 1b); and the Tepual stream (Fig. 1c). Phytoplankton from these three water bodies were collected with the help of a plankton net (45 $\mu \mathrm{m}$ mesh diameter) during an annual period, including the four seasons of the year (October 2016 and February, May and August 2017). Water temperature (current thermometer) and $\mathrm{pH}$ (pH paper) data were also taken.

The samples were observed and photographed in vivo with the help of a standard (Olympus CX31) and inverted light (Olympus CKX 41) microscope with a camera (518CU 5.OM CMOS) attached to them, and using an adhoc software to capture images and obtain micron size standards. Later on the samples were preserved in formalin $4 \%$ and stored at FICOLAB (Botany Department, University of Concepcion). The species were identified based on the traditional morphological (i.e. shape, size) and cytological observations (i.e. shape, color and number of chloroplasts, presence/ absence of pyrenoid, number and location of nucleus, when visible). The following identification keys were used: Cyanobacteria are given according to Komárek \& Anagnostidis (2000, 2005), Komárek \& Komárková (2002), with some modification based on recent data for the genus Planktothrix Gaget et al. (2015) and taxonomic changes at the generic level in Geitlerinema, Strunecký et al. (2017); Euglenophyceae are presented according to Ciugulea \& Triemer (2010), Marin et al. (2003), Tell \& Conforti (1986) and Hübber Pestalozzi (1955); Ochrophyta-Raphidiophyceae according to Wehr \& Sheath (2003); Dinophyceae based on Carty (2014); Chlorophyta-Chlorophyceae, according to Nakasawa et al. (2004) for the genus Asteroccoccus, Tsarenko (2011) for the genus Fusola and Pröschold (pers. comm. 2018) for the genus Chlamydocapsa, and finally, Streptophyta-Zygnematophyceae based on Sampaio (1944), Hirano (1955-1960), Grönblad et al. (1968), Prescott et al. (1981), Wehr \& Sheath (2003) and John et al. (2008).

\section{RESULTS}

The $\mathrm{pH}$ values ranged between 5.0-5.8 in Chapito pool, 5.86.0 in the "small dam" and $5.5-5.9$ in the Tepual stream, during the annual recollection period. The temperatures, on the other hand, fluctuated from 7.2 to $18{ }^{\circ} \mathrm{C}$ in Chapito pool, 7 to 14.8 ${ }^{\circ} \mathrm{C}$ in the "small dam" and 6.5 to $12.5^{\circ} \mathrm{C}$ in the Tepual stream. 

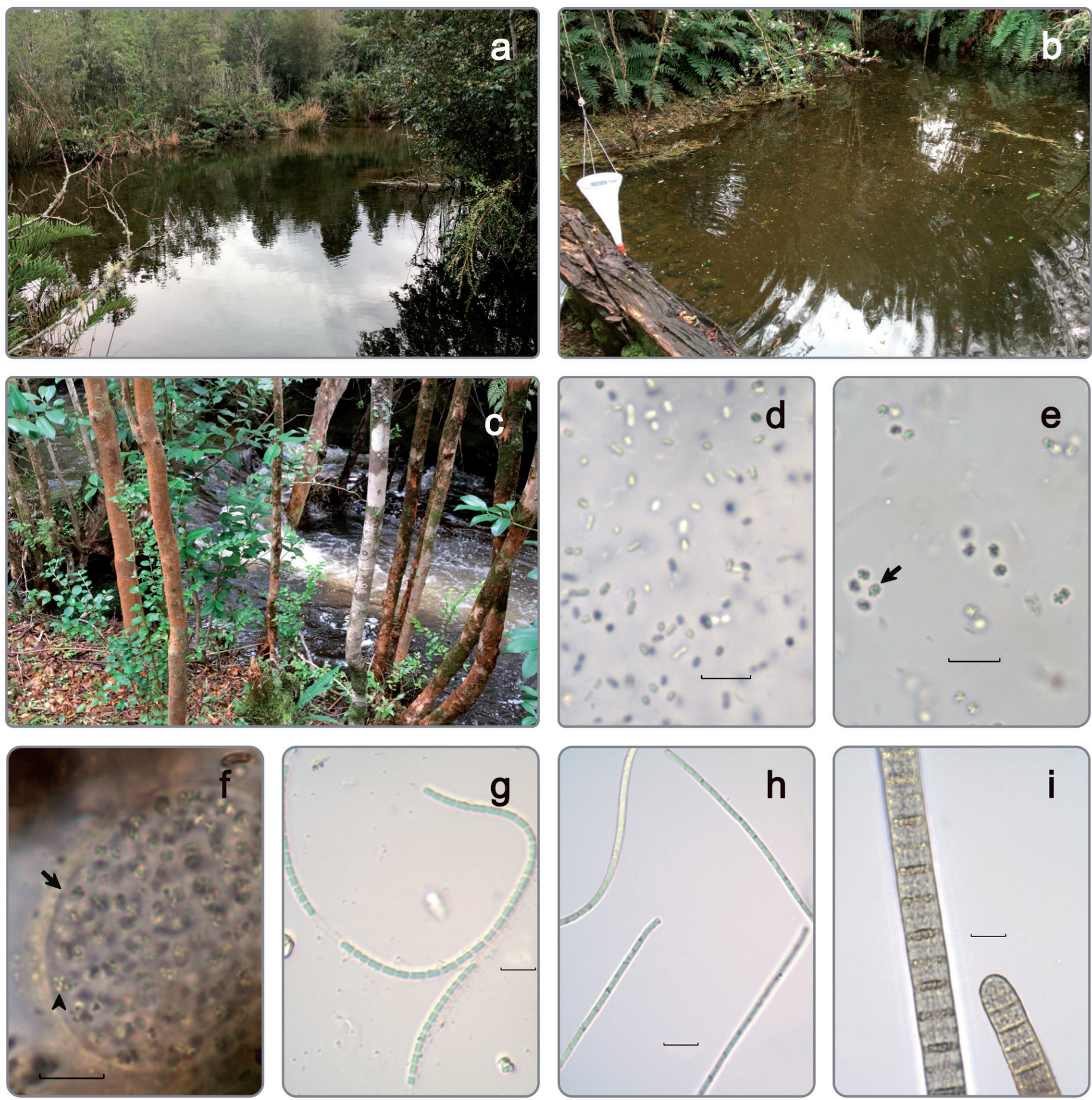

Figure. 1 (a-c) Places of collection. (a) Chapito pool, (b) small dam, (c) Tepual stream; (d) Anathece minutissima, detail of the cenobium; (e) Microcystis natans, detail of the cenobium, note aerotopes (arrow); (f) Microcystis firma, note firm mucilaginous envelop (arrow) and aerotopes (arrowhead); (g) Pseudanabaena minima; (h) Anagnostidinema cf. amphibium; (i) Tychonema cf. bornetii. Scale bar:10 $\mu$ m./ (a-c) Lugares de colecta. (a) Laguna Chapito, (b) Represita, (c) Riachuelo Tepual; (d) Anathece minutissima, detalle del cenobio; (e) Microcystis natans, detalle del cenobio, note presencia de aerótopos (flecha); (f) Microcystis firma, note firme envoltura mucilaginosa (flecha) y aerótopos (punta flecha); (g) Pseudanabaena minima; (h) Anagnostidinema cf. amphibium; (i) Tychonema cf. bornetii. Barra escala: 10 um. 
A total of 80 taxa were identified, being the StreptophytaZygnematophyceae the most abundant group with a dominance of Desmidiaceae (47 species). The genera with the higher number of species were Cosmarium (12), Closterium (11) and Staurastrum (8). The presence of the other taxonomic groups was as followed: Cyanobacteria with 14 taxa, Euglenophyceae with 12 taxa, ChlorophytaChlorophyceae with 5 taxa, and Dinophyceae and Ochrophyta-Raphidophyceae with one taxon each group.

The taxonomic identification is as followed:

\section{Cyanobacteria}

Order Chroococcales

Family Synechococcaceae

Anathece minutissima (West) Komárek, Kastovsky \& Jezberová 2011

Coenobia microscopic, gelatinous, elongate (125 $\mu \mathrm{m} \times 62.5$ $\mu \mathrm{m})$, enclosed by a fine, colorless, homogeneous mucilage with irregularly and more or less densely aggregated cells. Cells broadly oval or rod-shaped (0.8-1.0 $\mu \mathrm{m} \times 1.5 \mu \mathrm{m})$, greyish in color and with homogeneous content (Fig.1d).

Recorded for the first time for Chile.

Habitat: Chapito pool (August 2017).

\section{Family Chroococcaceae}

\section{Chroococcus minutus (Kuetzing) Naegeli 1849}

Coenobia with 4-8 cells enclosed by a homogeneous, hyaline sheath. Cells spherical or hemispherical after division, 4-6 $\mu \mathrm{m}$ in diameter, blue-greens, with granulate content.

Recorded for Chile (see Parra et al. 1982a).

Habitat: Chapito pool (August 2017).

Limnococcus limneticus (Lemmermann) Komárková, Jezberová, O. Komárek \& Zapomelová 2010

Coenobia with 4-8 cells irregularly distributed or in groups of 2 to 4 , enclosed by a wide, colorless, hyaline gelatinous envelope. Cells spherical, $5 \mu \mathrm{m}$ in diameter.

Recorded for Chile as Chroococcus limneticus Lemm. (see Parra et al. 1982a).

Habitat: Chapito pool (August 2017).

\section{Family Merismopediaceae}

Aphanocapsa elachista W. \& G.S. West 1894

Coenobia $80-110 \mu \mathrm{m}$ in diameter, with cells sparsely disposed, forming pairs after division. Cells spherical, with homogeneous content, 1.5-2.0 $\mu \mathrm{m}$ in diameter.

Recorded for Chile (see Almanza et al. 2016; as Microcystis elachista (W. et G.S. West) Starmach, see Parra et al. 1982a). Habitat: Chapito pool (February 2017).
Aphanocapsa incerta (Lemmermann) Cronberg et Komárek 1994

Coenobia 50-60 $\mu \mathrm{m}$ in diameter, with a great number of cells densely aggregated. Cells spherical, 1.8-2.8 $\mu \mathrm{m}$ in diameter, with homogeneous content.

Recorded for Chile (see Almanza et al. 2016; as Microcystis incerta Lemm., see Parra et al. 1982a).

Habitat: Chapito pool (February 2017).

\section{Family Microcystaceae}

Microcystis natans Lemmermann ex Skuja 1934

Coenobia microscopic, spherical to elongate, 60-250 um in diameter, with cells irregularly, not very densely packed. Mucilage colorless, homogeneous, fine. Cells spherical (1.5 $\mu \mathrm{m})$ to oval before division $(2 \mu \mathrm{m})$, with aerotopes (Fig.1e). Recorded for the first time for Chile. Habitat: Chapito pool (February 2017).

Microcystis firma (Kuetzing) Schmidle 1902

Coenobia microscopic, spherical or sub-spherical, 40-50 $\mu \mathrm{m}$ in diameter, with densely packed cells, enclosed by a mucilaginous envelop forming a distinct margin. Cells 1.7$2.1 \mu \mathrm{m}$ in diameter, with aerotopes (Fig.1f).

Recorded for the first time for Chile.

Habitat: Chapito pool (August 2017).

\section{Family Pseudanabaenaceae}

Pseudanabaena catenata Lauterborn 1915

Trichomes $1.5 \mu \mathrm{m}$ wide; cells cylindrical, 4-5 $\mu \mathrm{m}$ long. Recorded for Chile (see Almanza et al. 2016; Parra et al. 1982a).

Habitat: Chapito pool (February 2017).

Pseudanabaena minima (G.S. An) Anagnostidis 2001

Trichomes shorts, straights or curves, pale blue-greens, 1.8-2 $\mu \mathrm{m}$ wide. Cells isodiametric or longer than wide (2-4 $\mu \mathrm{m}$ long). Cellular content homogeneous (Fig.1g).

Recorded for the first time for Chile.

Habitat: Chapito pool and "small dam" (February 2017).

\section{Order Oscillatoriales}

Family Coleofasciculaceae

Anagnostidinema cf. amphibium (Agardh ex Gomont) Strunecky, Bohunická, Johansen et Komárek 2017.

Trichomes thins, longs, motile, light blue-greens, usually straight or slightly curves, not constricted at the cross-walls, 1.5-1.8 um wide, not or very slightly attenuated at the ends, not capitated. Cells 4-8 um long, pale blue-greens, with commonly one notorious refractive granule at either side of the cross-walls. Apical cell rounded, without calyptra. 
Necridial cells were not observed (Fig.1h).

Initially, we identified this taxon as Geitlerinema cf. unigranulatum (R. N. Singh) Komárek et Azevedo 2000. However, Bittencourt-Oliveira et al. (2009) suggested, based on morphology, ultrastructure and DNA data [sequence of the pcB-cpcA intergenic spacer (PC-IGS)] that G. unigranulatum is synonymous of Geitlerinema amphibium (C. Agardh ex Gomont) Anagnostidis 1989. Later on, Strunecký et al. (2017) revised the genus Geitlerinema and created a new genus, Anagnostidinema and included G. amphibium as synonymous of Anagnostidinema amphibium. To validate the identity of this taxon, molecular data is needed.

Recorded for the first time for Chile.

Habitat: Chapito pool (October 2016).

\section{Family Oscillatoriaceae}

Oscillatoria curviceps Agardh ex Gomont 1892

Trichomes blue-green, $10 \mu \mathrm{m}$ in diameter, slightly curved at the extremes which can or cannot be moderately attenuated, not constricted at the cross walls, where granules are usually present. Cells very short, 1.8-3.5 $\mu \mathrm{m}$. Apical cells widely round, not capitated, sometimes with thickening of the outer wall.

Recorded for Chile (see Parra et al. 1982a).

Habitat: Chapito pool (October 2016, February, May and August 2017).

\section{Family Phormidiaceae}

Tychonema cf. bornetii (Zucal) Anagnostidis et Komárek 1988 Trichomes brownish-green, straight, cylindrical, isopolar, not attenuated to the ends, 11-12 $\mu \mathrm{m}$ width, not constricted at the cross walls. Cells more or less isodiametric or slightly longer or shorter than wide (10-12 $\mu \mathrm{m}$ in length), notoriously granulated at the cross walls, and less notorious and more disperse granulation within the protoplasm. Apical cells broadly rounded with slightly thickened outer cell wall (Fig.1i). Even though most of the morphological attributes observed correspond with those of $T$. bornetii, molecular studies are needed to confirm this identification.

Recorded for the first time for Chile.

Habitat: Chapito pool (August 2017).

Planktothrix cf. clathrata (Skuja) Anagnostidis \& Komárek 1988 Trichomes blue-green, cylindrical, not narrowed to the ends, 6 to $9 \mu \mathrm{m}$ in diameter, with distinct constrictions at the cross walls. Cells always shorter than longer ( 2 to $4 \mu \mathrm{m}$ in length), with aerotopes. Apical cell rounded, not capitated (Fig. 2a).

Even though most of the morphological attributes observed correspond with those of $P$. clathrata, molecular studies are needed to confirm this identification.

Recorded for the first time for Chile.
Habitat: Chapito pool (February 2017).

Planktothrix cf. suspensa (Pringsheim) Anagnostidis et Komárek 1988

Trichomes blue-green, cylindrical, straight, 4-5 $\mu \mathrm{m}$ in width, not constricted at cross walls. Cells usually \pm isodiametric, or shorter and sometimes longer than wide (4-7 $\mu \mathrm{m}$ in length), with aerotopes. Apical cell rounded, in some individuals with slight thickness of the outer wall. As in the case of Planktothrix cf. clathrata, molecular studies are needed to confirm the identification of this taxon (Fig. 2b).

Recorded for the first time for Chile. Habitat: Chapito pool (August 2017).

\section{Dinoflagellata \\ Order Peridiniales \\ Parvodinium sp.}

Cells small, 22-29 $\mu \mathrm{m}$ long, 19-22 $\mu \mathrm{m}$ wide, ovoid, with numerous plastids yellowish-brown in color. The epitheca is bigger than the hypotheca; cingulum, wide. Apical pore visible. Plates thin, not visible in living organisms (Fig. 2c). This taxon probably corresponds to $P$. cf. umbonatum (Stein) Carty 2008 (E. Ascencio, pers.observ.).

The genus has been recorded for Chile as Peridinium [Peridium insconspicuum Lemm., Thomasson 1963, now Parvodinium insconspicuum (Lemm.) Carty].

Habitat: Chapito pool (February and August 2017).

\section{Ochrophyta - Rhaphidophyceae \\ Order Chattonellales}

Vacuolaria virescens Cienkowski 1870

Cells biflagellated, ovoid to ellipsoid in frontal view, 52-54 um long, 38-46 um wide. Chloroplasts numerous, discoid, lightgreen in color. Nucleus ellipsoidal (app. 10 um size) located in the center of the cell. Many refractile granules present in the cell periphery (Fig 2d).

Recorded for the first time for Chile.

Habitat: "small dam" (February 2017).

\section{Euglenophyta - Euglenophyceae \\ Order Euglenales}

Euglena intermedia (Klebs) Schmitz 1884 (= Euglena deses var. intermedia Klebs, 1883)

Cells metabolic, cylindrical with the anterior end blunt and the posterior tapering in a rounded tail, 105-120 $\mu \mathrm{m}$ long, 10$15 \mu \mathrm{m}$ wide. Pellicle finely striated. Chloroplasts numerous, discoid without pyrenoid; paramylon bodies rod-like. Flagellum about one sixth of the body length. Eyespot conspicuous.

Recorded for Chile (see Parra et al. 1982b).

Habitat: Chapito pool (Febrero 2017). 


\section{Euglena mutabilis Schmitz 1884}

Cells metabolic, elongate, slender, almost cylindrical, with the anterior end rounded and the posterior sharpened, 64$70 \mu \mathrm{m}$ long, 5-9 $\mu \mathrm{m}$ wide. Pellicle spirally striated; numerous plate - like chloroplasts, curved, with naked pyrenoid; small paramylon grains and central nucleus.

Recorded for Chile (see Parra et al. 1982b).

Habitat: Chapito pool (August 2017).

\section{Euglena oblonga Schmitz 1884}

Cells metabolic, spindle shaped, with anterior end rounded and the posterior ending in a blunt point or extended into a short tail, 41-50 $\mu \mathrm{m}$ long, 21-27 $\mu \mathrm{m}$ wide. Pellicle spirally striated. Chloroplasts numerous, deeply incised with long ribbon-shaped lobes and diplopyrenoids (Fig. 2e).

Recorded for the first time for Chile.

Habitat: Chapito pool (February and August 2017).

Lepocinclis spirogyroides Marin \& Melkonian 2003

Cells cylindrical or flattened with the anterior end rounded and the posterior ending in a colorless pointed tail, 75-90 um long, 9-14 um wide. Yellow-brown pellicle spirally striated, strips with brick-like ornamentation. Numerous small, discshaped chloroplasts. Two large paramylon bodies one anterior and one posterior to the nucleus, and smaller ones disperse within the cell (Fig. 2f).

Recorded for the first time for Chile.

Habitat: Chapito pool (August 2017).

\section{Lepocinclis steinii Lemmermann 1901}

Cells fusiform with the anterior end truncate and the posterior with short conical caudal appendix, 27-30 um long, 12-16 um wide. Pellicle longitudinally striated. Chloroplasts numerous, discoid. Two large lateral paramylon bodies (Fig. 2g).

Recorded for the first time for Chile.

Habitat: "small dam" (October 2016).

Monomorphina pyrum (Ehrenberg) Mereschkowsky emend. Kosmala et Zakrys 2007

Pear shaped cells 30-34 um long, 15-21 um wide; anterior end symmetric and posterior end with a long straight and finely pointed tail, 10-12 $\mu \mathrm{m}$ long. Pellicle with laevogyrate spirally keels. One orbicular perforated chloroplast. Two lateral paramylon plates.

Recorded as Phacus pyrum (Ehr.) Stein (see Dürrschmidt 1978).

Habitat: "small dam" (October 2016).
Trachelomonas abrupta Swirenko emend. Deflandre 1926

Lorica 30-34 um long, 15-21 um wide, ellipsoidal, with sides more or less curved, sometimes with a quadrangular tendency in longitudinal optical view, yellowish-brown, punctate, covered with minute spines, difficult to see.

Recorded for Chile (see Parra \& González 1978).

Habitat: Chapito pool (February 2017).

Trachelomonas hispida (Perty) Stein emend. Deflandre 1926 Lorica 23-33um long 19-24 um wide, broadly ellipsoidal, reddish-brown, punctate, covered with short conical spines, irregularly distributed; apical pore rounded by an annular thickening.

Recorded for Chile (see Pereira 2000; Parra et al. 1982b). Habitat: Chapito pool (February and August 2017).

Trachelomonas intermedia Dangeard 1901

Lorica 9-22 um long, 14-20 $\mu \mathrm{m}$ wide, sub-spherical or ellipsoidal, yellowish-brown, finely punctate; apical pore rounded by an annular thickening.

Recorded for Chile (see Dürrschmidt 1978).

Habitat: Chapito pool (August 2017).

\section{Trachelomonas pulcherrima Playfair 1915}

Lorica 20-24 um long, 9-12 um wide, ellipsoidal, very elongated, with poles broadly rounded, the posterior sometimes acuminated, light-yellow to brown, finely punctate. Recorded for Chile (see Parra \& González 1978). Habitat: Chapito pool (August 2017).

Trachelomonas raciborskii Woloszynska 1912

Lorica 30-40 $\mu \mathrm{m}$ long, 24-30 $\mu \mathrm{m}$ wide, ellipsoidal, thick, darkbrown, punctate, with conical and strong spines only close to the poles. Apical pore without a collar and surrounded by spines (Fig. 2h).

Recorded for the first time for Chile. Habitat: Chapito pool (February 2017).

Trachelomonas rotunda Svirenko emend. Deflandre 1926 Lorica 20-30 $\mu \mathrm{m}$ long, 19-30 $\mu \mathrm{m}$ wide, sub-spherical or broadly ellipsoidal, thick, dark-brown, strongly punctate; sometimes, with very short spines in its anterior region. Apical pore surrounded by an annular thickening (Fig. 2i).

Recorded for the first time for Chile. Habitat: Chapito pool (Agosto 2017). 

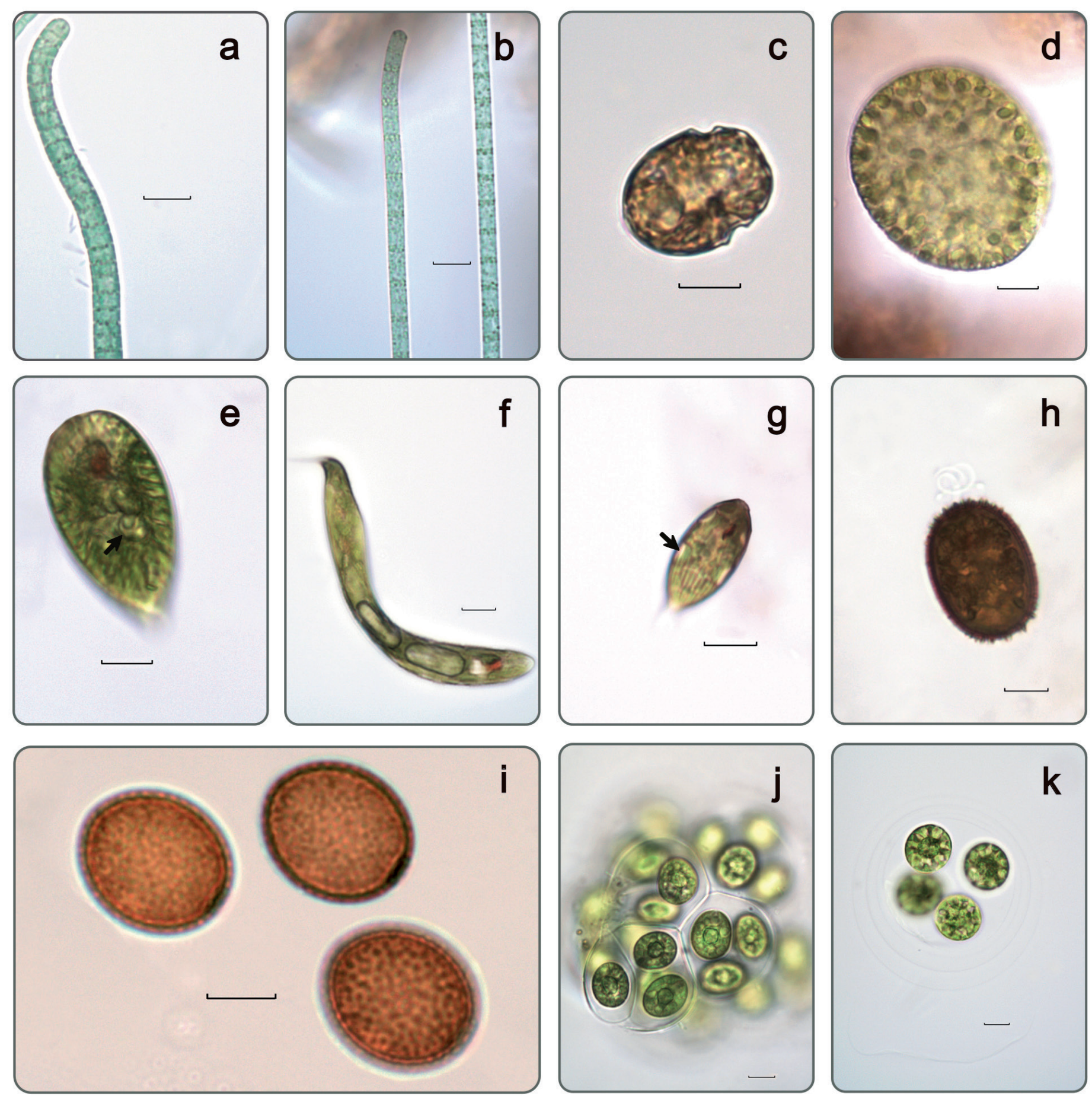

Figure 2. (a) Planktothrix cf. clathrata; (b) Planktothrix cf. suspensa; (c) Parvodinium sp.; (d) Vacuolaria virescens; (e) Euglena oblonga, diplopyrenoid (arrow); (f) Lepocinclis spirogyroides; (g) Lepocinclis steinii, paramylon (arrow); (h) Trachelomonas raciborskii; (i) Trachelomonas rotunda; (j) Asterococcus cf. limneticus; (k) Asterococcus cf. superbus. Scale bar: 10 mm. / (a) Planktothrix cf. clathrata; (b) Planktothrix cf. suspensa; (c) Parvodinium sp.; (d) Vacuolaria virescens; (e) Euglena oblonga, diplopirenoide (flecha); (f) Lepocinclis spirogyroides; (g) Lepocinclis steinii, paramilon (flecha); (h) Trachelomonas raciborskii; (i) Trachelomonas rotunda; (j) Asterococcus cf. limneticus; (k) Asterococcus cf. superbus. Barra escala: $10 \mu \mathrm{m}$. 


\section{Chlorophyta - Chlorophyceae \\ Orden Chlamydomonadales}

Asterococcus cf. limneticus G. M. Smith 1918

Coenobia 45 to $100 \mu \mathrm{m}$ in diameter, composed of spherical to ellipsoidal cells (16-20 $\mu \mathrm{m}$ long $\times 12-15 \mu \mathrm{m}$ wide), forming groups of 4 to 16 cells embedded in a mucilage. Chloroplast, one, stellate, with a central pyrenoid (Fig. 2j).

According to Nakazawa et al. (2004) and based on morphological attributes this taxon belongs to Asterococcus limneticus; however, molecular data is needed to confirm its identity.

Recorded for the first time for Chile.

Habitat: Chapito pool (February, May 2017).

Asterococcus cf. superbus (Cienkowski) Scherffel 1908

Cells spherical, single or in small groups of four (17-30 $\mu \mathrm{m}$ in diameter) with a wide mucilaginous lamellate (4) envelope. Chloroplast one, central, with numerous arms radiating from a central pyrenoid (Fig. 2k).

As in the previous taxon, molecular data are needed to confirm the identity of this organism as Asterococcus superbus.

Recorded for Chile (see Parra et al. 1983a).

Habitat: Chapito pool (May 2017).

\section{Chlamydocapsa cf. lobata Broady 1977}

Cells spherical or sub-spherical, 8-10 $\mu \mathrm{m}$ in diameter, distributes in groups of 8 within a wide mucilaginous envelope. Presence of a fine mucilage around each cell or groups of cells. Chloroplast parietal, lobate with a central, basal pyrenoid (Fig. 3a).

Recorded for the first time for Chile.

Habitat: Chapito pool (August 2017).

Chlamydocapsa cf. planctonica (West \& G.S. West) Fott

Coenobia 60 to $85 \mu \mathrm{m}$ in diameter, composed of numerous cells surrounded by a hyaline mucilaginous envelope. Cells irregularly distributed, ovoid, 10-14 (-17) um long, 7-9 (-12) $\mu \mathrm{m}$ wide. Chloroplast parietal, cup-shaped, with one pyrenoid, spherical, sub-median in position (Fig. 3b).

Recorded for Chile (see Parra et al. 1983a).

Habitat: Chapito pool (May 2017), "small dam" (February 2017).

\section{Order: Sphaeropleales}

Fusola cf. viridis J. W. Snow 1903

Cells in groups of four alternately disposed within a colorless mucilage, fusiform, 30-35 um long, 7-8 $\mu \mathrm{m}$ wide. Chloroplast parietal, laminar, with distinct central pyrenoid (Fig. 3c).

Recorded for the first time for Chile.

Habitat: Chapito pool (May 2017).

\section{Streptophyta - Zygnematophyceae \\ Order Desmidiales}

Actinotaenium globosum (Bulnheim) Förster ex Compére 1976

Cells 31.3-38.3 $\mu \mathrm{m}$ long, 23.1-24.4 $\mu \mathrm{m}$ wide. Isthmus little marked 21.8-23.1 $\mu \mathrm{m}$ wide. Semicells globular, apex rounded. Cell wall dotted.

Recorded for Chile (see Williamson 2004) and as Cosmarium globosum Bulnheim (see Parra et al. 1983b).

Habitat: Chapito pool (August 2017), "small dam" (February 2017).

Bambusina brebisonii Kützing ex Kützing 1849

Cells barrel-shaped 25.1-27.8 $\mu \mathrm{m}$ long, 17-19.1 $\mu \mathrm{m}$ wide. Cells are united by their apices to form filaments; semicells pyramidal-truncated.

Recorded for Chile (see Williamson 2004; Parra et al. 1983b). Habitat: Chapito pool (October 2016, February and May 2017).

Closterium angustatum Kützing ex Ralfs 1848

Cells long, slightly curved, in the mid-region with parallel margins, toward the ends only slightly narrowed, 183-450 $\mu \mathrm{m}$ long, 13-23 $\mu \mathrm{m}$ wide. Apices are capitated. Chloroplasts with 3 to 5 longitudinal ridges; pyrenoids aligned. Cell wall with transverse bands and longitudinal ribs widely separated (Fig. 3d).

Recorded for the first time for Chile.

Habitat: Chapito pool (October 2016, February, May and August 2017), "small dam" (October 2016, February 2017).

\section{Closterium ehrenbergii Meneghini ex Ralfs 1848}

Cells large, moderately curved $400 \mu \mathrm{m}$ long, 60-70 $\mu \mathrm{m}$ wide, swollen at the center and attenuating towards the rounded apices. Chloroplasts with 4-7 longitudinal ridges, with many pyrenoids scattered. Cell wall finally striated.

Recorded for Chile (see Pereira et al. 2000; Parra et al. 1983b). Habitat: Chapito pool (February and August, 2017).

\section{Closterium gracile Brébisson ex Ralfs 1848}

Cells long, narrow, 140-190 $\mu \mathrm{m}$ long, $5 \mu \mathrm{m}$ wide, slightly curved but straight at the center, tapered at both ends which become slightly incurved. Chloroplast with 4-7 pyrenoids aligned. Cell wall smooth.

Recorded for Chile (see Almanza et al. 2016; Williamson 2004; EULA 2013; Parra et al. 1983b).

Habitat: Chapito pool (October 2016, February, May and August 2017), "small dam"(February 2017).

Closterium jenneri Ralfs 1848

Cells small, evenly curved, 65-80 $\mu \mathrm{m}$ long, $10 \mu \mathrm{m}$ wide, 
margins almost parallel in the central part that narrow slightly at the ends; apices rounded. Chloroplast with 3-5 longitudinal ridges, 2-5 pyrenoids in each semicell. Cell wall striated although sometimes difficult to detect (Fig. 3e).

Recorded for Chile (Borge 1906)

Habitat: Chapito pool (October 2016, February and August 2017).

\section{Closterium kuetzingii Brébisson 1856}

Cells $300 \mu \mathrm{m}$ long, 13-20 $\mu \mathrm{m}$ wide, with a broad fusiformlanceolate middle region, attenuating abruptly into long, narrow ends. Chloroplasts with 4-6 longitudinal ridges and 4-10 pyrenoids scattered. Cell wall finely striated.

Recorded for Chile (see Parra et al. 1983b, 1999, 2005; Williamson 2004; Theoduloz \& Parra 1984).

Habitat: Chapito pool (October 2016 and May 2017), "small dam" (October 2016).

Closterium libellula Focke ex Nordstedt 1873

Cells right, fusiform 170-181.7 $\mu \mathrm{m}$ long, 40-41.7 $\mu \mathrm{m}$ wide. Chloroplasts with 5-12 longitudinal ridge, 3-6 pyrenoids. Cell wall smooth.

Recorded for Chile (see Parra et al. 1983b).

Habitat: Chapito pool (October 2016), "small dam" (February 2017).

Closterium navicula (Brébisson) Lütkemüller 1905

Cells small, right, fusiform 74-80 $\mu \mathrm{m}$ long, 17-20 $\mu \mathrm{m}$ wide; apices broad, rounded to subtruncate. Terminal vacuoles spherical with 4 crystals. Chloroplasts 3-5 longitudinal ridge, 1-3 pyrenoids in each semicell. Cell wall smooth (Fig. 3f).

Recorded for the first time for Chile.

Habitat: Chapito pool (October 2016, February and August 2017).

\section{Closterium parvulum Nägeli 1849}

Cells strongly curved, $136 \mu \mathrm{m}$ long, $15 \mu \mathrm{m}$ wide. Chloroplasts with 2-3 longitudinal ridges, 2-5 pyrenoids in each semicell. Cell wall smooth.

Recorded for Chile (see Almanza et al. 2016; EULA 2016; Theoduloz \& Parra 1984; Parra et al. 1983b).

Habitat: Chapito pool (October 2016, February and August 2017), "small dam" (May 2017).

\section{Closterium praelongum Brébisson 1856}

Cells long, narrow, slightly curved 360-430 $\mu \mathrm{m}$ long, 20 $\mu \mathrm{m}$ wide; apices with inverse curvature. Chloroplasts with 3 longitudinal ridges and several pyrenoids. Cell wall finely striated.
Recorded for Chile (see Williamson 2004; Parra et al. 1983b). Habitat: "small dam" (October 2016 and February 2017).

Closterium ralfsii Brébisson ex Ralfs 1848

Cells elongate-cylindrical, slightly curved, $413-511 \mu \mathrm{m}$ long, 33-40 $\mu \mathrm{m}$ wide. Chloroplast 2-3 longitudinal ridges, 6-9 pyrenoids in each semicell. Cell wall striated, girdle bands present.

Recorded for Chile (see Parra et al. 1983b).

Habitat: Chapito pool (February and August 2017).

Closterium striolatum Ehrenberg ex Ralfs 1848

Cell lightly curved, $276 \mu \mathrm{m}$ long, $32 \mu \mathrm{m}$ wide. Chloroplasts 5-6 longitudinal ridges, 5-9 pyrenoids in each semicells. Cell wall markedly striated with transverse bands.

Recorded for Chile (see Williamson 2004; Parra et al. 1983b). Habitat: "small dam" (October 2016).

\section{Cosmarium binum Nordstedt 1880}

Cells large, 64-71 $\mu \mathrm{m}$ long, 48-54 $\mu \mathrm{m}$ wide. Semicells hemispherical - trapezoid; lateral margins with 9 crenations, 5 across the apex; crenations bigranulate. The protuberance in the middle region of the semicell bears 7 vertical rows of granules, and between this protuberance and the isthmus a row of large granules. Sinus deep closed linear; isthmus 13 $\mu \mathrm{m}$ wide.

Recorded for Chile (see Parra et al. 1983b).

Habitat: Chapito pool (October 2016 and August 2017).

\section{Cosmarium aff. bipunctatum Børgesen 1891}

Cells small, almost as broad as long, $25.4 \mu \mathrm{m}$ long, $23.6 \mu \mathrm{m}$ wide. Semicells widely trapezoid, lower and upper angles obtuse, sides convex, apex widely truncated, margin crenate with 6 crenation at the apex and 6 along each side. Sinus linear, narrow gently dilated at the end; isthmus $7.8 \mu \mathrm{m}$ wide (Fig. 3g). This taxon closely resembles Cosmarium bipunctatum Børgesen; however, it was impossible to observe, in the analyzed specimens, the two granules transversely arranged in the center of each semicell.

Recorded for the first time for Chile. Habitat: Chapito pool (August 2017).

\section{Cosmarium connatum Brébisson ex Ralfs 1848}

Cells large 64-66 $\mu \mathrm{m}$ long, 48-49 $\mu \mathrm{m}$ wide. Semicells elliptical, apex broadly rounded. Isthmus $45-46 \mu \mathrm{m}$ wide. Cell wall covered with small pores interspersed with many dots.

Recorded for Chile (see Parra et al. 1983b).

Habitat: Chapito pool (October 2016 and August 2017). 


\section{Cosmarium laeve Rabenhorst 1868}

Cells small, $25 \mu \mathrm{m}$ long, $19 \mu \mathrm{m}$ wide. Semicells truncatedpyramidal, flat apex. Sinus deep, narrow, linear; isthmus $8 \mu \mathrm{m}$ wide. Cell wall scarcely punctate.

Recorded for Chile (see EULA 2013; Theoduloz \& Parra 1984; Parra et al. 1983b).

Habitat: Chapito pool (August 2017).

\section{Cosmarium portianum Archer 1860}

Cells $41.3 \mu \mathrm{m}$ long, $23.9 \mu \mathrm{m}$ wide. Semicells oblong-ellipsoidal, reniform. Sinus deep, open; isthmus elongated $13 \mu \mathrm{m}$ wide. Cell wall with granules.

Recorded for Chile (see Williamson 2004; Zúñiga et al. 1986; Parra et al. 1983b).

Habitat: Chapito pool (October 2016, February and August 2017).

\section{Cosmarium pseudopyramidatum P. Lundell 1871}

Cells 59.2-62.4 $\mu \mathrm{m}$ long and $38.8 \mu \mathrm{m}$ wide. Semicell pyramidal or semi-elliptical with flattened apex, basal angles roundedangular. Sinus deep, narrow, open internally; isthmus 11.5$12.9 \mu \mathrm{m}$ wide. Cell wall punctate.

Recorded for Chile (see, Zúñiga et al. 1986; Parra et al. 1983b). Habitat: Chapito pool (October 2016, August 2017).

\section{Cosmarium pseudoretusum F. Ducellier 1918}

Cells of medium size, 29-31 $\mu \mathrm{m}$ long, 22-25 $\mu \mathrm{m}$ wide. Semicell pyramidal, truncated apex, lateral margins with a basal lobe projecting outward, irregularly 2-undulate. Sinus straight, narrow; isthmus 5-6 $\mu \mathrm{m}$ wide. Cell wall punctate (Fig. 3h).

Recorded for the first time for Chile.

Habitat: Chapito pool (October 2016, February and August 2017).

\section{Cosmarium reniforme (Ralfs) Archer 1874}

Cells 48.8-50 $\mu \mathrm{m}$ long, 30.5-32.17 $\mu \mathrm{m}$ wide. Semicells reniform. Sinus deep, narrow; isthmus $11.93 \mu \mathrm{m}$ wide. Cell wall granulate.

Recorded for Chile (see Parra et al. 1983b).

Habitat: Chapito pool (October 2016, February and August 2017).

Cosmarium sportella Brébisson ex Kützing 1849

Cells slightly longer than broad, 55-60 $\mu \mathrm{m}$ long, 48.5-51 $\mu \mathrm{m}$ wide. Semicell shortly pyramidal-truncated, with lower angles broadly rounded, apexes widely truncate and straight. Sinus deep, narrow, linear; isthmus $16.1 \mu \mathrm{m}$ wide. Cell wall granulate, about 8-9 granules visible on each lateral margin, apex smooth or with 5 small marginal granules (Fig. 3i).

Reported for the first time for Chile
Habitat: Chapito pool (October 2016).

\section{Cosmarium subprotumidum Nordstedt 1876}

Cells small 24-25.4 $\mu \mathrm{m}$ long, 17.3-18 $\mu \mathrm{m}$ wide. Semicells trapezoidal with flattened apex and crenate lateral sides. Cell wall granulate.

Reported for Chile (see Parra et al. 1983b).

Habitat: Chapito pool (February 2017).

\section{Cosmarium subtumidum Nordstedt 1878}

Cells 35-36 $\mu \mathrm{m}$ long, 26-28 $\mu \mathrm{m}$ wide. Semicell semicircularpyramidal with broadly rounded basal and apical angle; apex widely truncated. Isthmus $9.8 \mu \mathrm{m}$ wide. Cell wall finely punctate, but looks smooth.

Reported for Chile (see Almanza et al., 2016; Parra et al. 1983b).

Habitat: Chapito pool (February and August 2017).

Cosmarium aff. wenmaniae Croasdale 1968

Cells 53.1-56.6 $\mu \mathrm{m}$ long, 52.3-55.3 $\mu \mathrm{m}$ wide. Semicells reniform with cell margin faintly crenulate. Sinus open abruptly and widely broad; isthmus $24.3-29.8 \mu \mathrm{m}$ wide. Cell wall rather thick and evenly coarsely scrobiculate. Chloroplast with two pyrenoids per semicell (Fig. 3j).

Reported for the first time for Chile.

Habitat: Chapito pool (October 2016, August 2017).

Desmidium grevillei (Kützing ex Ralfs) De Bary 1858

Cells 17-25 $\mu \mathrm{m}$ long, 34-42 $\mu \mathrm{m}$ wide, with an oval contour in front and rectangular in side view, which join together forming twisted filaments.

Reported for Chile as Desmidium cylindricum Greville (see Parra et al. 1983b).

Habitat: "small dam" (May 2017).

Euastrum binale (Turpin) Ehrenberg ex Ralfs 1848

Cells small, 19.7-20.8 $\mu \mathrm{m}$ long, 15.5-16.5 $\mu \mathrm{m}$ wide. Sinus deep, closed, linear; isthmus 4-4.4 $\mu \mathrm{m}$ wide. Semicells trapezoid-pyramidal-truncated; apex with a shallow open V-shaped incision marked by acute angles. Cell wall smooth. Reported for Chile (see Parra et al. 1983b).

Habitat: Chapito pool (August 2017).

\section{Euastrum oblongum Ralfs 1848}

Cells oblong-elliptical, 150-172.7 $\mu \mathrm{m}$ long, 70-92 $\mu \mathrm{m}$ wide. Sinus deep, narrow, linear; isthmus 21.8-30.9 $\mu \mathrm{m}$ wide. Semicells 5 -lobed (one terminal and four lateral). Cell wall punctate.

Reported for Chile (see Parra et al. 1983b).

Habitat: "small dam" (October 2016, February 2017). 
Gonatozygon aculeatum W.N. Hastings 1892

Cells cylindrical, $160-250 \mu \mathrm{m}$ long, $14-20 \mu \mathrm{m}$ wide. Cells unite loosely with each other to form filaments. Cell wall covered with fine spines 5-6.15 $\mu \mathrm{m}$ long.

Reported for Chile (see Pereira et al. 2000; Zúñiga et al. 1986; Parra et al. 1983b).

Habitat: Chapito pool (October 2016, February, May and August 2017), "small dam" (February 2017).

\section{Gonatozygon pilosum Wolle 1882}

Cells cylindrical, straight, 81.5-103.4 $\mu \mathrm{m}$ long, 6.7-13.3 $\mu \mathrm{m}$ wide. Wall densely covered with small straight spines.

Reported for Chile (see EULA, 2011; Parra et al. 1983b, 1999, 2005).

Habitat: Chapito pool (October 2016, February and August 2017), "small dam" (May 2017).

\section{Hyalotheca dissiliens Brébisson ex Ralfs 1848}

Cells short slightly contracted in the medium 11-17 $\mu \mathrm{m}$ long, 21-23 $\mu \mathrm{m}$ wide, joined by truncated apices into long filaments, with mucilaginous sheath.

Reported for Chile (see Pereira et al. 2000; Theoduloz \& Parra 1984; Parra et al. 1983b).

Habitat: Chapito pool (October 2016, August 2017).

\section{Micrasterias americana Ehrenberg ex Ralfs 1848}

Cells compressed dorsoventrally, 118.9-127.4 $\mu \mathrm{m}$ long, 102.7 $\mu \mathrm{m}$ wide, deeply constricted with an open sinus. Semicells 5- lobed, polar lobe with two smaller ones that are arranged alternating one forward and one backward, separated from the lateral lobes by a deep incision; lateral lobes divided into two lobules with shallow incisions dissecting them. Cell wall granulate (Fig. 3k).

Recorded for the first time for Chile.

Habitat: Chapito pool (October 2016, February, May and August 2017).

Netrium interruptum (Brébisson ex Ralfs) Lütkemüller 1902 Cells cylindrical, $190 \mu \mathrm{m}$ long, 36,6 $\mu \mathrm{m}$ wide, abruptly narrow towards the apexes. Vacuoles globular, large, terminal, with 1 crystal each. Chloroplasts are subdivided transversely giving the impression of 4 per cell.

Recorded for Chile (see Parra et al. 1983b)

Habitat: Chapito pool (February 2017).

Netrium oblongum (De Bary) Lütkemüller 1902

Cells oblong-elliptical with widely rounded ends, $150 \mu \mathrm{m}$ long, $46 \mu \mathrm{m}$ wide. Chloroplast lobed and striated with longitudinal and moderately dissected ridges, 1-2 pyrenoids.

Recorded for Chile (see Parra et al. 1983b)
Habitat: Chapito pool (October 2016).

Pleurotaenium ehrenbergii (Ralfs) De Bary 1858

Cells straight, cylindrical, 270-290 $\mu \mathrm{m}$ long, 30-35 $\mu \mathrm{m}$ wide. Semicells with a small basal inflation, apex truncate with 4 to 5 rounded tubercles. Chloroplasts narrow longitudinal bands, each with a row of small pyrenoids.

Recorded for Chile (see Williamson 2004; Pereira et al. 2000; Parra et al. 1983b).

Habitat: Chapito pool (February 2017), Tepual stream (August 2017).

Staurodesmus dejectus (Brébisson) Teiling 1954

Cells tri-radiate, 23.6-26.3 $\mu \mathrm{m}$ long, 20.9-25.4 $\mu \mathrm{m}$ wide. Semicells cup-shaped, apices with a short spine projected upwards. Isthmus 5-10 $\mu \mathrm{m}$ wide.

Recorded for Chile (see EULA 2011, 2012; Parra et al. 1983b, 1999, 2003, 2005; Theoduloz \& Parra 1984).

Habitat: Chapito pool (October 2016, February and May 2017).

Staurodesmus dickiei (Ralfs) S. Lillieroth 1950

Cells tri-radiate, $29 \mu \mathrm{m}$ long, 23.6-27.2 $\mu \mathrm{m}$ wide. Semicells elliptical with short, convergent spines. Isthmus 7.2-8.1 $\mu \mathrm{m}$ wide.

Recorded for Chile (see EULA 2012; Parra et al. 1983b, 1999, 2005; Zúñiga et al. 1986).

Habitat: Chapito pool (October 2016 and August 2017).

\section{Staurodesmus glaber (Ralfs) Teiling 1948}

Cells 2-3-4 radiate, 21.8-36.6 $\mu \mathrm{m}$ long, 15.4-35.4 $\mu \mathrm{m}$ wide. Semicells inverse triangles, angles with short incurved spines. Isthmus 6.3-9 $\mu \mathrm{m}$ wide.

Recorded for Chile (see Parra et al. 1983b).

Habitat: Chapito pool (October 2016 and February 2017).

Staurastrum brachiatum Ralfs ex Ralfs 1848

Cells 27-36.5 $\mu \mathrm{m}$ long, 25-48 $\mu \mathrm{m}$ wide. Sinus acute, almost rectangular; isthmus $9 \mu \mathrm{m}$ wide. Semicells triangular, arms or processes of variable length, with bifurcated ends. Cell wall smooth. Polar view 3 radiated.

Recorded for Chile (see Parra et al. 1983b).

Habitat: Chapito pool (October 2016).

\section{Staurastrum dilatatum Ehrenberg ex Ralfs 1848}

Cells without arms or processes, 29-30 $\mu \mathrm{m}$ long, $25 \mu \mathrm{m}$ wide. Semicells elliptical, upper margin slightly convex, lower inflated, lateral angles rounded or truncate-rounded. Isthmus 6.8-10 $\mu \mathrm{m}$ wide. Cell wall with small granules. Polar view 4-radiate. Recorded for Chile (see Parra et al. 1983b). Habitat: Chapito pool (May 2017). 

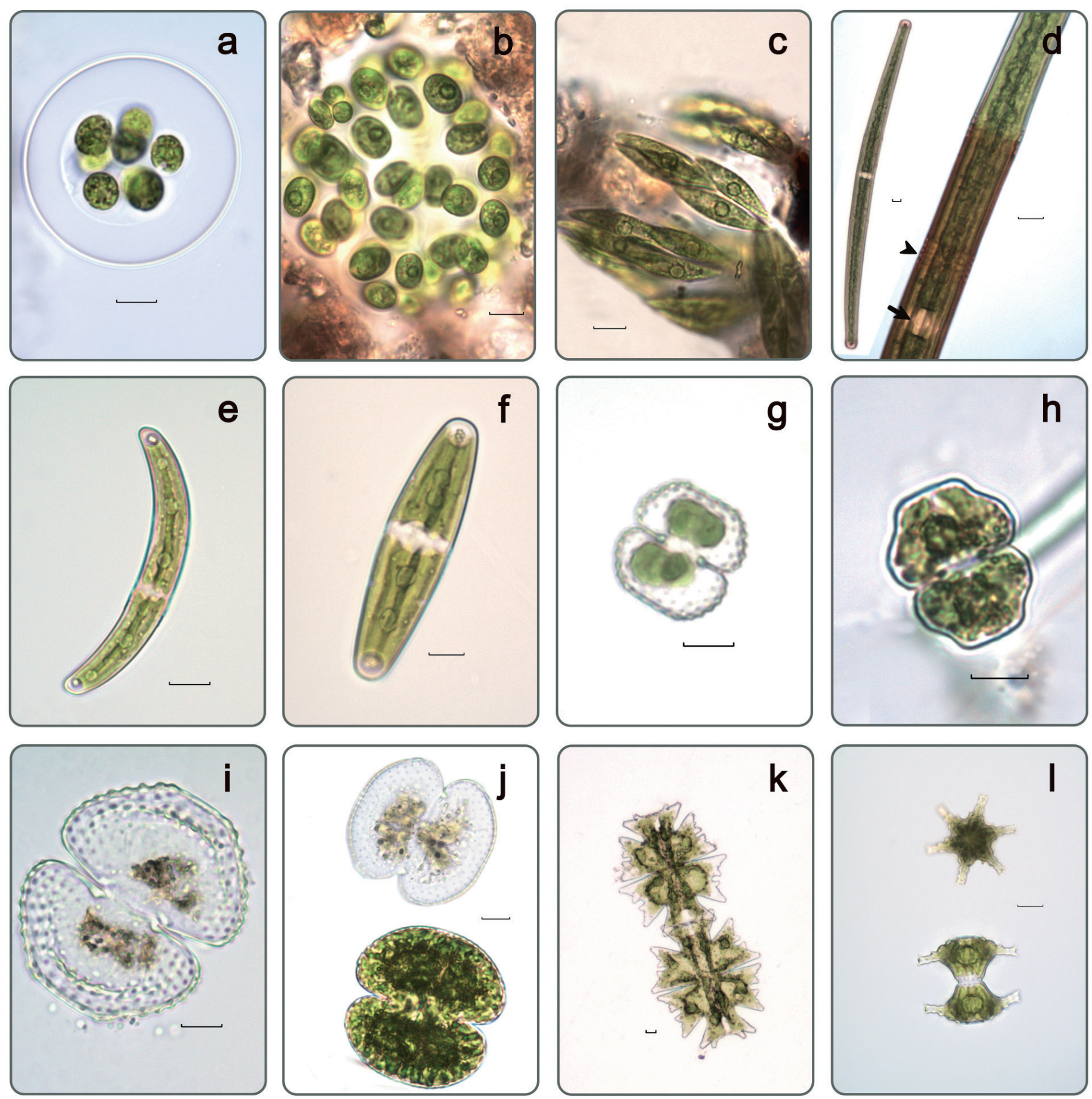

Figure 3. (a) Chlamydocapsa cf. lobata; (b) Chlamydocapsa cf. planctonica; (c) Fusola cf. viridis; (d) Closterium angustatum, ribs (arrow), bands (arrowhead); (e) Closterium jenneri; (f) Closterium navicula; (g) Cosmarium aff. bipunctatum; (h) Cosmarium pseudoretusum; (i) Cosmarium sportella; (j) Cosmarium aff. wenmaniae; (k) Micrasteria americana; (I) Staurastrum margaritaceum. Scale bar: 10 um. / (a) Chlamydocapsa cf. lobata; (b) Chlamydocapsa cf. planctonica; (c) Fusola cf. viridis; (d) Closterium angustatum, costas (flecha), bandas (punta de flecha); (e) Closterium jenneri; (f) Closterium navicula; (g) Cosmarium aff. bipunctatum; (h) Cosmarium pseudoretusum; (i) Cosmarium sportella; (j) Cosmarium aff. wenmaniae; (k) Micrasteria americana; (I) Staurastrum margaritaceum. Barra escala: 10 um. 
Staurastrum furcigerum (Brébisson) W. Archer 1861

Cells 40-55.2 $\mu \mathrm{m}$ long, 47.8-55 $\mu \mathrm{m}$ wide (with processes). Semicells elliptical with short processes with concentric series of teeth, and a pair of extra-large teeth at the end. Isthmus 14.7-15 $\mu \mathrm{m}$ wide. Polar view 3-radiate.

Recorded for Chile (see Parra et al. 1983b, 1999, 2005; Theoduloz \& Parra 1984).

Habitat: Chapito pool (August 2017).

\section{Staurastrum manfeldtii Delponte 1877}

Cells, $38 \mu \mathrm{m}$ long, $40 \mu \mathrm{m}$ wide (with processes). Semicells cup-shaped, processes horizontal or slightly convergent ending in 3 spines. Isthmus $10 \mu \mathrm{m}$ wide. Cell wall smooth, but with granules on each process. Polar view 3-radiate.

Recorded for Chile (see Zúñiga et al. 1986; Parra et al. 1983b). Habitat: Chapito pool (February 2017).

Staurastrum margaritaceum Meneghini ex Ralfs 1848

Cells 32-39 $\mu \mathrm{m}$ long and 36-44 $\mu \mathrm{m}$ wide (with processes). Semicells cup-shaped, with short processes that end in 4 small spines. Isthmus $10 \mu \mathrm{m}$ wide. Cell wall with granules, with a concentric ring of granules in the isthmus. Polar view 6-radiate (Fig 3I).

Recorded for Chile (see Williamson 2004).

Habitat: Chapito pool (October 2016, February, May and August 2017).

Staurastrum rotula Nordstedt 1869

Cells 46.1-50 $\mu \mathrm{m}$ long, 26.1-27.7 $\mu \mathrm{m}$ wide; $73.9 \mu \mathrm{m}$ wide (with processes). Isthmus $14.6 \mu \mathrm{m}$ wide. Semicells subhexagonal; processes relatively long covered with small spines and ending in three teeth. Polar view 9-radiate.

Recorded for Chile (see González \& Inostroza 2017; EULA, 2012, 2016).

Habitat: Chapito pool (May 2017).

\section{Staurastrum sebaldi Reinsch 1866}

Cells, 50-54 $\mu \mathrm{m}$ long and 58-75 $\mu \mathrm{m}$ wide (with processes). Isthmus 13-15 $\mu \mathrm{m}$ wide. Semicells cup-shaped; processes convergent, short, with warts and spines, ends truncated with 3-5 spines. Polar view 3-radiate.

Recorded for Chile (see Almanza et al. 2016; Asprey et al. 1964).

Habitat: Chapito pool (February and August 2017).

\section{Staurastrum subavicula (West) West \& G.S.West 1894}

Cells without arms, $31.8 \mu \mathrm{m}$ long and $33.6 \mu \mathrm{m}$ wide (with spines). Isthmus $12 \mu \mathrm{m}$ wide. Semicells sub-elliptical; apices with a circle of spines and margins with 5-6 bifid spines. Polar view triangular.
Recorded for Chile (see Parra \& González 1977). Habitat: Chapito pool (October 2016, May and August 2017).

Xanthidium antilopaeum Kützing 1849

Cells $67 \mu \mathrm{m}$ long (with spines), $48 \mu \mathrm{m}$ (without spines). Semicells hexagonal, each of the four lateral angles extended into a pair of two simple spines. Cell wall finely punctate. Recorded for Chile (see Parra et al. 1983b, 1999, 2003, 2005, Williamson 2004).

Habitat: "small dam" (February 2017).

The filamentous Zygnematalean genera Mougeotia, Spirogyra and Zygnema were also present in Chapito pool most of the year, but because no reproductive structures (zygotes) were found, it was not possible to identified them at species level, so were not included in this study. Most of the taxa identified were present in the Chapito pool and the "small dam". The Tepual stream was inhabited mainly by diatoms (not included in this study) and occasionally by some filamentous Zygnematalean (i.e. Zygnema sp.). No other group of microalgae was found in this lotic environment.

\section{DISCUSSION}

Most of the species were found inhabiting the Chapito pool (63 species- 77.7\%): 8 species (9.8\%) only in the "small dam" and ten species (12.3\%) were present in both water bodies. On the other hand, few species (mostly diatoms, not included in this study) were present in the Tepual stream, probably because it was a lotic environment with fast moving water.

The range of $\mathrm{pH}$ values found during the annual recollection period (5.0 to 6.1) denote the presence of acidophilus water ( $\mathrm{pH}<6.5$, Štastný 2010), a suitable environment for desmids which were the main group present in the water bodies studied. This group of greens occur exclusively in freshwater habitats, with a clear preference for oligo- to mesotrophic, slightly acidic environments (Kouwets 2008). According to this author, the largest species diversity can be found in shallow, mesotrophic lakes with rich stands of submerged macrophytes such as Myriophyllum, Potamogeton and Utricularia.

The $70.2 \%$ of the desmids species identified in this investigation are from acidophilus environments (Štastný 2010); on the other hand, the $48.6 \%$ are indicators of mesotrophic environments and $21.6 \%$ of meso-oligotrophic habitats (Štastný 2010). The most common species in term of presence and relative abundance was Closterium angustatum, a taxon characteristic for acidic and oligo-mesotrophic environments according to Štastný (2010). They followed 
it, in term of presence, Staurastrum margaritaceum (acidoligo), Micrasterias americana (acid-meso) and Gonatozygon aculeatum (acid-meso). Within the other taxonomic groups, the blue-green Chroococcus minutus is known to inhabit mostly in shallower oligotrophic water bodies (Whitton 2008), the euglenoid Euglena mutabilis prevails in acidic habitats (Wolowski 2008) as well as the yellow-green flagellate Vacuolaria virescens (Pentecost 2008).

Even though all the samples come from phytoplankton, only few species of desmids are truly planktonic (Brook 1959). Brook stated that most species of genera Closterium and Cosmarium are confined to benthic habitat, while those belonging to Stauratrum are among the more numerous of planktonic desmids. Thus, many of the desmids encounter within this study are tychoplanktonic (dislodge by chance from macrophytes and get into the net) or benthic (may get into the net when dragged it close to the bottom) in their habitat, taking into consideration that Chapito pool is a very shallow water body. The same is true for most of the Oscillatoriales species and Pseudanabaena found, which are known from benthic, tychoplanktic or periphytic environments.

Taxonomically, desmid taxa are generally distinguished on the basis of a large variety of more or less clearly defined morphological characters, mainly relating to cell wall outline and sculpture (Kouwets 2008). However, the taxonomic value of these characters, especially when they show a different degree of development, depend on the hierarchical level to be used. Their use at infraspecific taxonomic level (i.e. subspecies, varieties, forms) could led to inconsistences according to Kouwets (2008). Most of the genera found in this investigation are monophyletic (i.e. Closterium -Denboh et al. 2001, Staurastrum- Gontcharov \& Melkonian 2005, Gonatozygon- Gontcharov et al. 2004, Micrasterias - Škaloud et al. 2011, Bambusina- Gontcharov \& Melkonian 2011 , Pleurotaenium- Škaloud et al. 2012 and Xanthidium- Stastný et al. 2013), and the species found could be easily identified since their morphological characters are prominent, well defined and clearly visible under the light microscopy. On the other hand, in Cosmarium, a polyphyletic genus according to Gontcharov \& Melkonian $(2011,2008)$, the identification was harder because some characters were inconspicuous and less visible (such as cell wall sculpturing and pore partner). The taxonomy of Cosmarium are not resolved yet, so that any of the 12 species identify here may belong to this genus or may be included into new genera.

Within the Chlorophyta Chlorophyceae, the genera Asterococcus and Chlamydocapsa were very common in Chapito pool. No molecular studies have been done in either genera. Based on the study of Nakazawa et al. (2004) on Asterococcus, two species were identified in this investigation:
A. cf. limneticus and A. cf. superbus, mainly based on cell organization (single or in groups) and presence or absence of striated sheath around the cells. For Chlamydocapsa, Ettl \& Gärtner (1988) recognized six species. Pröschold (2018, pers. comm.) identified as $C$. cf. lobata one of the species found in this study. The other species probably corresponds to $C$. planctonica since morphology fits well with the description of the life cycle of this taxon described by Skuja (1948).

Fusola viridis was found only in one occasion in Chapito pool (May 2017), and is the type and the only species of the genus Fusola Snow 1903. Elakatothrix viridis (J.W.Snow) Printz (1914), was the known name assigned to this microalga, but currently is regarded as it synonym (Guiry \& Guiry 2018). F. viridis is nowadays a species accepted taxonomically. No molecular studies exist on neither organism, so their real taxonomic positions are still uncertain.

Most of the euglenoids taxa were found in Chapito pool, which could indicate the presence of organic matter in that water body with the subsequent bacterial activity.

Within the cyanobacteria, the most difficult group in term of taxa identification based on morpho-cytological attributes were the filamentous, and among them, the genera Planktothrix, Tychonema and Anagnostidinema. Two species of Planktothrix were present in the water bodies studied: $P$. cf. clathrata and P. cf. suspensa. According to Komárek \& Komárková (2004), the infrageneric classification within Planktothrix is complex. Thus, $P$. clathrata forms a group with $P$. compressa. Both species belong to the "thicker" types and are distinguished only slightly by dimensions, so they are probably conspecific (Komárek \& Komárková 2004). The same occurs with $P$. suspensa which form a cluster with $P$. agardhii (Komárek \& Komárková 2004) and according to Davis et al. (2003), the separation of these species is doubtful according to present criteria.

Tychonema bornetii was only found once, but abundantly, in Chapito pool (August 2017). Only the type species of the genus (Tychonema tenue (Skuja) Anagnostidis \& Komárek 1988), based on molecular phylogeny (16s rDNA), supports taxonomically the genus, since other species studied (T. bornetii not included) reveal that the genus is poly/paraphyletic.

Anagnostidinema is a recently described new genus erected by Strunecký et al. (2017), in order to include species previously assigned to Geitlerinema that differ from its congeneric taxa in the absence of capitate apical cells, and their phylogenetic molecular placement according to the 16S rRNA gene sequences. The morphological attributes exhibited by the individuals observed in this research, even though identified at first as Geitlerinema cf. unigranulatum, [= synonymous of Geitlerinema amphibium (Bittencourt-Oliveira et al. 2009)] fits well with the genus Anagnostidinema (apical 
cells cylindrically rounded) and with the species A. amphibium, but molecular studies are needed to validate its identity.

One species of the genus Oscillatoria (O. curviceps) was also present and easily identified by morphological attributes. However, according to Komárek et al. (2014) this genus requires a taxonomic revision since molecular studies of some species have shown that the genus is paraphyletic or polyphyletic. They recall a lack of molecular data for most species of the genus.

Among the coccoid cyanobacteria, the identification was not as difficult as the previous group. The genus Microcystis was present in Chapito pool with two species: M. natans and M. firma. The genus is monophyletic (Komárek et al. 2014, Komárek \& Komárková 2002) and its traditional species even though showed negligible molecular differences, differ in their morphology (i.e. coenobial form, mucilage structure, cell diameter, density of cells within the coenobium) and ecophysiology, so according to those authors, the traditional morpho-species category should be maintained.

Even though, Komárek et al. (2014) have categorized the genus Aphanocapsa as those morpho-genera that need taxonomic revision, the two species found in this study (A. incerta and A. elachista) were clearly differentiated by morphological attributes.

The recently erected genus Anathece (Komárek et al. 2011, originally a sub genus of Aphanothece) was also found in Chapito pool (August 2017) represented by one species: $A$. minutissima. However, the taxonomic stability of this genus is not completely supported, since the same authors found a high genetic similarity (16S rRNA) between species assigned to Anathece (coenobial) and to Cyanobium (unicellular), and they argue that their morphological differences may be a physiological expression to herbibory and/or to high irradiance. The above authors agree that more studies are needed to decide if both genera can be fused into only one genus.

The two species of Pseudanabaena inhabiting the Chapito pool were Ps. catenata and Ps. minima. According to Komárek \& Anagnostidis (2005), the genus is polyphyletic, and there is not a clear separation of this genus with Limnothrix. Both genera need to be studied using polyphasic approach (Komárek et al. 2014).

Within Chroococcaceae, two genera inhabit these water bodies: Chroococcus (Chr. minutus) and Limnococcus (L. limneticus). Both genera are currently recognized as distinct genera (Guiry \& Guiry 2018), and the species found here were easily identify by their morphological attributes (cells disposition within the coenobium and amplitude of the mucilaginous envelope around the cells).

The only dinoflagellate commonly present in the water bodies (Chapito pool, pH ranged from 5.0 to 5.8 ) within the park was Parvodinium (probably P. cf. umbonatum (F. Stein) Carty according to Ascencio, pers.observ. 2018). Carty (2014) considered this species as acid tolerant since she found it everywhere. The species was also reported as dominant in acidic lakes (Znachor \& Nedoma 2014; Pérez et al. 1994). Parvodinium umbonatum is considered a species complex, whose circumscription is in progress (Kretschmann et al. 2018, Moestrup \& Calado 2018).

Also, Vacuolaria virescens was the only Raphidiophyceae inhabiting within the park and specifically in the "small dam". This species tends to occur most commonly in small and usually rather acidic waters (Pentecost 2008), as it was in this water body ( $\mathrm{pH}$ 5.8-6).

To conclude, this study enriches the biological knowledge already known from the park (i.e. trees, ferns, mosses, lichens, shrubs, birds, rodents, amphibian, some insect group), and constitute the first basic approach done on the photosynthetic biota of its water bodies. Only the Crustacean have been previously studied in the Chapito pool (De los Rios-Escalante \& Ruedas 2014). The great diversity of desmids found is comparable with what Parra \& González (1977) observed in 2 (out of 9) acidophilus freshwater bodies (Natri and Tarahuín lakes) from Chiloe Island, even though those water bodies were much bigger and deeper than the study sites. More than half (61.7\%) of the species of desmids found in this research were also present in the nine water bodies from Chiloe Island. On the contrary, a much less desmids biodiversity ( 25 species) was found by Theoduloz \& Parra (1984) in three acidophilus freshwater bodies (Lynch, Ojo del Mar and temporal Tres Puentes lagoons) from the extreme south of Chile, and there was only $10.6 \%$ of species coincidence. Finally, the taxonomic results denote the great diversity of microalgae inhabiting these pristine and peculiar environments and will serve as a basis for further studies (a) in similar ecological areas within the country and/or (b) focused on the taxonomy and systematics of a particular species or species complexes.

\section{ACKNOWLEDGMENTS}

The authors thank Dr. Luis Corcuera's encouragement to do this study and for providing all the park facilities for its execution. Also, we acknowledge the support of FICOLAB which provided the infrastructure (i.e. microscopes and literature) necessary to perform this work. Finally, we thank Dr. Thomas Pröschold for its useful help with the Chlorophyceae taxonomy, and the English revision of the manuscript. 


\section{REFERENCES}

Almanza, V., Parra, O., Bicudo, de M.C.E., González, M.A., López. M., Urrutia, R. 2016. Floraciones de fitoplacton y variación de la estructura comunitaria fitoplanctónica en tres lagos someros eutróficos de Chile Central. Gayana Botánica 73(2): 191-205.

Asprey, G., Benson-Evans, K., Furet, J.E. 1964. A contribution to the study of South American Freshwater Phytoplankton. Gayana Botánica 10: 1-19.

Bittencourt-Oliveira, M.C., Moura, A.N., Oliveira, M.C., Massola Jr, S.N. 2009. Geitlerinema species (Oscillatoriales, Cyanobacteria) revealed by cellular morphology, ultrastructure and DNA sequencing. Journal of Phycology 45(3): 716-725.

Borge, O. 1906. Süsswasser-Chlorophyceen von Feuerland und Isla Desolacion. In: Botaniska studier tillägnade F. R. Kjellman den 4 November 1906. (Anon. Eds) Vol. 6, pp. 21-34. Upsala: Uppsala, Almqvist \& Wiksells boktryckeri-a.-b.

Brook, A. J. 1959. The status of desmids in the plankton and the determinations of phytoplankton quotients. Journal of Ecology 47: 429-445.

Campos, H., Soto, D., Steffen, W., Aguëro, G., Parra, O., Zúñiga, L. 1994a. Limnological studies of Lake del Toro (Chile) morphometry, physics, chemistry and plankton. Archiv für Hydrobiologie, Supplement 99: 199-215.

Campos, H., Soto, D., Steffen, W., Aguëro, G., Parra, O., Zúñiga, L. 1994b. Limnological studies of Lake Sarmiento (Chile): a subsaline lake from Chilean Patagonia. Archiv für Hydrobiologie, Supplement 99: 217-234.

Campos, H., Soto, D., Parra, O., Steffen, W., Agüero, G. 1996. Limnological studies of Amarga lagoon, Chile: a saline lake in Patagonia, South America. International Journal of Salt Lake Research 4: 301-314.

Carty, S. 2014. Freshwater dinoflagellates of North America. Comstock Publishing Associates, Cornell University Press, Ithaca. 260 pp.

Ciugulea, I., Triemer, R. 2010. A Color Atlas of Photosynthetic Euglenoids, Michigan State University Press, East Lansing. 204 pp.

Davis, Ph.A., Beard, S.J., Walsby, A.E. 2003. Variation in filament width and gas vesicles of red and green isolates of Planktothrix spp. Algological Studies 108: 15-29.

De los Ríos, P., Soto, D. 2009. Estudios limnológicos en lagos y lagunas del Parque Nacional Torres del Paine $\left(51^{\circ} \mathrm{S}\right.$ Chile). Anales del Instituto de la Patagonia (Chile) 37(1): 63-71.

De los Ríos-Escalante, P., Ruedas, T. 2014. Crustaceans in freshwater bodies in a coastal protected area $\left(41^{\circ} \mathrm{S}\right.$,
Katalapi Park, Chile). Crustaceana 87(11-12): 1469-1472.

Denboh, T., Hendrayanti, D., Ichimura, T. 2001. Monophyly of the genus Closterium and the order Desmidiales (Charophyceae, Chlorophyta) inferred from nuclear small subunit rDNA data. Journal of Phycology 37: 1063-1072.

Dürrschmidt, M. 1978. Relationen zwischen Phytoplankton und physikalisch-chemischen Faktoren in FliessgewässerÖkosystemen im Kleinen Süden Chiles. InaguralDissertation, University of Giessen, Germany. 195 pp.

Ettl, H. Gärtner, G. 1988. Chlorophyta II (Tetrasporales, Chlorococcales, Gloeodendrales). In: Ettl, H., Gerloff, J. \& Heynig, H. (eds.), Sußwasserflora von Mitteleuropa. Vol. 10. Gustav Fischer Verlag, Jena. 436 pp.

EULA. 2011. Análisis de fitoplancton en muestras de agua. Informe final. Universidad de Concepción, Centro EULAChile, Concepción. 184 pp.

EULA. 2012. Análisis del fitoplancton de muestras de agua (agosto 2011-marzo 2012). Informe Final preparado para la DGA-MOP. Universidad de Concepción, Centro EULA-Chile. Concepción. 45 pp.

EULA. 2013. Agua, situaciones de emergencia, factibilidad técnica para el abastecimiento de agua potable desde un sistema de lagunas urbanas. Informe final Proyecto INNOVA CHILE CORFO Código 10 CREC-8453.

EULA. 2016. Análisis de fitoplancton en muestras de agua. Informe Final para Ministerio de Obras Públicas. S.I.T. N 403 ID: 1019-8-LE 16.

Gaget, V., Welker, M., Rippka, R., Marsac, N.T. 2015. A polyphasic approach leading to the revision of the genus Planktothrix (Cyanobacteria) and its type species, $P$. agardhii, and proposal for integrating the emended valid botanical taxa, as well as three new species, Planktothrix paucivesiculata sp. nov. ${ }^{\mathrm{ICNP}}$, Planktothrix tepida sp. nov. ICNP, and Planktothrix serta sp. nov. ${ }^{\text {ICNP }}$, as genus and species names with nomenclatural standing under the ICNP. Systematic and Applied Microbiology 38: 141-158.

Gontcharov, A.A., Marin, B., Melkonian, M. 2004. Are combined analyses better than single gene phylogenies? A case study using SSU rDNA and rbcL sequence comparisons in the Zygnematophyceae (Streptophyta). Molecular Biology and Evolution 21: 612-624.

Gontcharov, A.A., Melkonian, M. 2005. Molecular phylogeny of Staurastrum Meyen ex Ralfs and related genera (Zygnematophyceae, Streptophyta) based on coding and noncoding rDNA sequence comparisons. Journal of Phycology 41: 887-899.

Gontcharov,A.A., Melkonian, M. 2008. In search of monophyletic taxa in the family Desmidiaceae (Zygnematophyceae, Viridiplantae): the genus Cosmarium. American Journal Botany 95(9): 1079-1095. 
Gontcharov, A.A., Melkonian, M. 2011. A study of conflict between molecular phylogeny and taxonomy in the Desmidiaceae (Streptophyta, Viridiplantae): Analyses of 291 rbcL sequences. Protist 162: 253-267.

González, M.A, Inostroza, I. de L. 2017. Manual taxonómico y fotográfico de géneros fitoplanctónicos (excl. Diatomeas) de 7 lagunas del Gran Concepción, Concepción. 172 pp. https://issuu.com/manualtaxfotfitoplanctonchile/docs/ manualtaxfotfitoplanctonchile

Grönblad, R., Scott, A.M., Croasdale, H. 1968. Desmids from Sierra Leone, tropical West Africa. Acta Botanica Fennica p. 78: 1-41.

Guiry, M.D. 2018. AlgaeBase. World-wide electronic publication, In: Guiry, M.D., Guiry, G.M. (eds.), National University of Ireland, Galway. http://www.algaebase.org. Accessed 17 Jan 2018.

Hirano, M. 1955-1960. Flora Desmidiarium Japonicarum. Contributions from the Biological Laboratory, Kioto University 1,2,4,5,7,9,11: 1-474, 54 láms.

Hüber-Pestalozzi, G. 1955. Das Phytoplankton des Süßwasser, Die Binnengewässer 16(4): 1-1135.

John, D.M., Whitton, B.A., Brook, A.J. (eds.). 2008. The Freshwater Algal Flora of the British Isles. An Identification Guide to Freshwater and Terrestrial Algae. The Natural History Museum. Cambridge University Press. 702 pp.

Kretschmann, J., Owsianny, P.M, Žerdoner-Čalasan, A., Gottschling, A. 2018. The Hot Spot in a Cold Environment: Puzzling Parvodinium (Peridiniopsidaceae, Peridiniales) from the Polish Tatra Mountains. Protist 169(2): 206-230.

Komárek, J., Anagnostidis, K. 2000. Cyanoprokaryota. 1. Teil: Chroococcales. In: Ettl, H., Gärtner G., Heynig H., Mollenhauer, D. (eds.), Süßwasserflora von Mitteleuropa. pp. 1-548. Heidelberg, Berlin. Spektrum Akademischer Verlag,

Komárek, J., Anagnostidis, K. 2005. Cyanoprokaryota -2. Teil/ 2nd Part: Oscillatoriales. - In: Büdel, B., Krienitz, I., Gärtner, G., Schagerl, M. (eds.), Süßwasserflora von Mitteleuropa, 19/2. Elsevier/Spektrum, Heidelberg, Berlin. 759 pp.

Komárek, J., Komárková, J. 2002. Review of the European Microcystis morphospecies (Cyanoprokaryotes) from nature. Czech Phycology 2: 1-24.

Komárek, J., Komárková, J. 2004. Taxonomic review of the cyanoprokaryotic genera Planktothrix and Planktothricoides (Cyanoprokaryota). Czech Phycology 4: 1-18.

Komárek J., Kastovsky, J., Jezberová, J. 2011. Phylogenetic and taxonomic delimitation of the cyanobacterial genus Aphanothece and description of Anathece gen. nov.
European Journal of Phycology 46(3): 315-326.

Komárek, J., Kaštovský, J., Mareš, J., Johansen, J.R. 2014. Taxonomic classification of cyanoprokaryotes (cyanobacterial genera) 2014, using a polyphasic approach. Preslia 86: 295-335.

Kouwets, F.A.C. 2008. The species concepts in desmids: the problem of variability, infraspecific taxa and the monothetic species definition. Biologia 63: 877-883.

Marin, B., Palm, A., Klingberg, M., Melkonian, M. 2003. Phylogeny and taxonomic revision of plastid-containing euglenophytes based on SSU rDNA sequence comparisons and synapomorphic signatures in the SSU rRNA secondary structure. Protist 154: 99-145.

Moestrup, Ø., Calado, A.J. 2018. Dinophyceae. In: Büdel, B., Gärtner, G., Krienitz, L., Schagerl M., (eds.), Süßwasserflora von Mitteleuropa 6, pp. 1-561. Springer Spektrum, Berlin, Germany.

Nakazawa, A., Yamada, T., Nozaki, H. 2004. Taxonomic study of Asterococcus (Chlorophyceae) based on comparative morphology and rbcL gene sequences. Phycologia 43(6): 711-721.

Palau, A., Caputo, L. 2013. Caracterización limnológica de las masas de agua continentales de Huinay (X Región de Los Lagos, Chile). ENDESA. (España). 119 pp.

Parra, O., González, M. 1976. Guía bibliográfica y de distribución de las Cianófitas de Chile (excluyendo el continente Antártico). Gayana Botánica 32: 1-55.

Parra, O., González, M. 1977. Desmidiaceas de Chile III Desmidiaceas de la Isla de Chiloé. Gayana Botánica 34: 1-103.

Parra, O., González, M. 1978. Freshwater Algae of Chiloe Island, Chile. Nova Hedwigia 30: 873-924.

Parra, O., González, M., Dellarossa, V., Rivera, P., Orellana, M. 1982a. Manual taxonómico del fitoplancton de aguas continentales con especial referencia al fitoplancton de Chile. Editorial Universidad de Concepción. Vol. I: Cyanophyceae. 70 pp.

Parra, O., González, M., Dellarossa, V., Rivera, P., Orellana, M. 1982b. Manual taxonómico del fitoplancton de aguas continentales con especial referencia al fitoplancton de Chile. Editorial Universidad de Concepción. Vol. III: Chryptophyceae, Dinophyceae y Euglenophyceae. 99 pp.

Parra, O., González, M., Dellarossa, V. 1983a. Manual taxonómico del fitoplancton de aguas continentales con especial referencia al fitoplancton de Chile. Editorial Universidad de Concepción. Vol. IV: Chlorophyceae, Parte I: Volvocales, Tetrasporales, Chlorococcales y Ulothricales. 151 pp.

Parra O., González, M., Dellarossa, V. 1983b. Manual 
taxonómico del fitoplancton de aguas continentales con especial referencia al fitoplancton de Chile. Editorial Universidad de Concepción. Vol. V: Chlorophyceae, Parte II: Zygnematales. 152-353 pp.

Parra, O., Basualto, S., Urrutia, R., Valdovinos, C. 1999. Estudio comparativo de la diversidad fitoplanctónica de cinco lagos de diferentes niveles de eutroficación del área litoral de la región del Biobio (Chile). Gayana Botánica 56(2): 93-108.

Parra, O., Valdovinos, C., Urrutia, R., Cisternas, M., Habit, E., Mardones, M. 2003. Caracterización y tendencias tróficas de cinco lagos costeros de Chile Central. Limnetica 22(2): 51-83.

Parra, O., Valdovinos, C., Basualto, S., Urrutia, R. 2005. Diversidad fitoplanctónica de los lagos nahuelbutanos (Chile Central). In: Smith-Ramírez, C., Armesto, J., Valdovinos, C. (eds.), Historia, biodiversidad y ecología de los bosques costeros de Chile. pp. 146-157. Editorial Universitaria.

Pentecost, A. 2008. Phylum Rhaphidophyta. In: John, D.M., Whitton, B.A., Brook, A.J. (eds.), The Freshwater Algal Flora of the British Isles. An Identification Guide to Freshwater and Terrestrial Algae. pp. 208-210. The Natural History Museum. Cambridge University Press.

Pereira, I., Reyes, G., Kramm, V. 2000. Cyanophyceae, Euglenophyceae, Chlorophyceae, Zygnematophyceae y Charophyceae, en arrozales de Chile. Gayana Botánica 57(1): 29-53.

Perez, E.A.A., Decosta, J., Havens, K.E. 1994. The effects of nutrient addition and $\mathrm{pH}$ manipulation in bag experiments on the phytoplankton of a small acidic lake in West Virginia, USA. Hydrobiologia 291: 93-103.

Prescott, G.W., Croasdale, H.T., Vinyard, W.C., Bicudo, C.E. de M. 1981. A Synopsis of North American Desmids: Part II. Desmidiaceae: Placodermae. Section 3. University of Nebraska Press. 720 pp.

Rivera, P., Cruces, F. 2008. Fragilaria capucina Desm. var. mesogongyla Frenguelli, Una diatomea presente en la zona norte de la Cordillera de los Andes (Chile), con comentarios sobre la variabilidad del número de procesos labiados en algunos géneros arafidales. Gayana Botánica 65(2): 131-138.

Rivera, P., Cruces, F. 2015. Frankophila sudamericaca sp. nov. a new diatom species (Bacillariophyta) found in Salar de Aguas Calientes and Salar de Huasco, high altitude Andean localities in northern Chile. Gayana Botánica 72(2): 373-376.

Rivera, P., Cruces, F., Vila, I. 2002. Primera cita de Stephanodiscus agassizensis Hakansson \& Kling (Bacillariophyceae) en Chile. Gayana Botánica 59(2): 79-86.
Rose, D.T., Cox, E.J. 2002. Diatoms (Bacillariophyta) from different benthic habitats within seven upland lakes in the Laguna San Rafael National Park, Chile. Boletín del Museo Nacional de Historia Natural (Chile) 51: 11-41.

Sampaio, J. 1944. Desmidias portuguesas. Boletim da Sociedade Broteriana Coimbra Portugal 18: 5-538.

Škaloud, P., Nemjová, K., Veselá J., Cerná, K., Neustupa, J. 2011. A multilocus phylogeny of the desmid genus Micrasterias (Streptophyta): Evidence for the accelerated rate of morphological evolution in protists. Molecular Phylogenetics and Evolution 61: 933-943.

Škaloud, P., Stastný, J., Nemjová, K., Mazalová, P., Poulícková, A., Neustupa, J. 2012. Molecular phylogeny of baculiform desmid taxa (Zygnematophyceae). Plant Systematics and Evolution 298: 1281-1292.

Skuja, H. 1948. Taxonomie des Phytoplanktons einiger Seen in Uppland, Schweden. Symbolae Botanicae Upsalienses 9(3): 1-399. 39 pls.

Soto, D., Campos, H., Steffen, W., Parra, O., Zúñiga, L. 1994. The Torres del Paine lake district (Chilean Patagonia): a case of potentially $\mathrm{N}$-limited lakes and ponds. Archiv für Hydrobiologie, Supplement 99: 181-197.

Št'astný, J. 2010. Desmids (Conjugatophyceae, Viridiplantae) from the Czech Republic; new and rare taxa, distribution, ecology. Fottea 10(1): 1-74.

Štastný. J., Škaloud, P., Langenbach. D., Nemjová, K., Neustupa, J. 2013. Polyphasic evaluation of Xanthidium antilopaeum and Xanthidium cristatum (Zygnematophyceae, Streptophyta) species complex. Journal of Phycology 49: 401-416.

Strunecký, O., Bohunická, M., Johansen, J.R., Capková, K., Raabová, L., Dvořák, P., Komárek, J. 2017. A revision of the genus Geitlerinema and a description of the genus Anagnostidinema gen. nov. (Oscillatoriophycidae, Cyanobacteria). Fottea 17(1): 114-126.

Tell, G., Conforti, V. 1986. Euglenophyta pigmentadas de la Argentina. Bibliotheca Phycologica 75: 1-301.

Theoduloz, C., Parra, O. 1984. Desmidiaceas (Saccodermae y Placodermae) de Chile. IV. Desmidiaceas del sistema de lagos de la Cordillera del Paine y alrededores. Gayana Botánica 41(3-4): 201-224.

Thomasson, K. 1963. Araucanian Lakes. Plankton studies in North Patagonian with notes on terrestrial vegetation. Acta Phytogeographica Suecica 47: 1-139.

Tsarenko, P.M. 2011. Chlorococcales. In: Tsarenko, P.M., Wasser, S.P., Nevo, E. (eds.) Algae of Ukraine: diversity, nomenclature, taxonomy, ecology and geography. Volume 3: Chlorophyta, pp. 232-264. Ruggell A.R.A. Gantner Verlag K.-G.

Villalobos, L., Woelfl, S, Parra, O., Campos, H. 2003. Lake 
Chapo: a base line study of a deep, oligotrophic North Patagonian lake prior to its use for hydroelectricity generation: II. Biological properties. Hydrobiologia 510: 225-237.

Wehr, J.D., Sheath, R.G. (eds.). 2003. Freshwater Algae of North America: Ecology and Classification. Elsevier-Academic Press. 918 pp.

Williamson, D. 2004. Some Desmids from southern Chile. Algological Studies 112: 105-121.

Whitton, B. 2008. Phylum Cyanophyta (Cyanobacteria). In: John, D.M., Whitton, B.A., Brook, A.J. (eds.), The Freshwater Algal Flora of the British Isles. An Identification Guide to Freshwater and Terrestrial Algae, pp. 25-122. The Natural History Museum. Cambridge University Press, UK.

Woelfl, S., Villalobos, L., Parra, O. 2003. Trophic parameters and method validation in Lake Riñihue (North Patagonia,
Chile) from 1978-1997. Revista Chilena de Historia Natural 76(3): 459-474.

Wolowski, K. 2008. Phylum Euglenophyta. In: John, D.M., Whitton, B.A., Brook, A.J. (eds.), The Freshwater Algal Flora of the British Isles. An Identification Guide to Freshwater and Terrestrial Algae, pp. 144-179. The Natural History Museum. Cambridge University Press, UK.

Zúñiga, L., Dominguez, P., Carvajal, M.A. 1986. Distribución espacio temporal del fitoplancton de la laguna El Plateado (Valparaíso, Chile). Anales del Museo de Historia Natural de Valparaíso 16: 41-54.

Znachor P., Nedoma, J. 2004. Cell specific primary production of autotrophic and mixotrophic phytoplankton in acidified lakes of the bohemian forest. Archiv für. Hydrobiologie, Supplement 152 (Algological Studies 112): 141-155.

Received: 20.03.2019

Accepted: 29.07.2019 